\title{
As Darkness Deepens: The Right to be Forgotten in the Context of Authoritarian Constitutionalism
}

\author{
Matthias Goldmann*
}

(Received 27 February 2020; accepted 28 February 2020)

\begin{abstract}
There is no point in denying the significance of the Right to be forgotten for the state of judicial dialogue in Europe. It vindicates the position of the BVerfG as a court deserving international recognition for advancing the law in the crucial field of data protection. Nevertheless, restricting the scope of analysis to the narrow context of judicial dialogue misses the wider context of the rise of authoritarian constitutionalism in certain EU Member States. In this respect, it is of the highest significance that the decisions on the Right to be forgotten effectively eliminate the imagined normative hierarchy between domestic and EU law that provided the basis for the BVerfG's jurisprudence ever since Solange I and Maastricht. Moreover, by reasserting the primacy of EU law, the BVerfG strengthens the position of embattled judges in Poland facing disciplinary action for implementing the primacy of EU law. The concern shown by some members of the First Senate for the situation in Poland corroborates this reading.
\end{abstract}

Keywords: authoritarian constitutionalism; data protection; primacy of EU law; fundamental rights; rule of law crisis

\section{A. Introduction}

The double coup on the Right to be forgotten by the Bundesverfassungsgericht (BVerfG) ${ }^{1}$ prompted most commentators to focus on the significance of these decisions for the decadeold scuffle between Karlsruhe and Luxembourg. Assessments vacillate between hailing the decisions as stabilizing the relationship between the courts ${ }^{2}$ and rejecting them as yet another outburst of constitutional self-assertion. ${ }^{3}$ Common to these accounts is the dominance of institutional dynamics between Europe's highest courts as an explanatory factor. Fundamental rights adjudication, it seems, is to a considerable extent determined by the institutional context of the various courts involved and the desires of their judges to maintain or change it. Accordingly, the BVerfG's decisions in Right to be forgotten I and II have to be read as a reaction to the strengthening of the CJEU's position thanks to increasing legal harmonization and its at times courageous and

\footnotetext{
${ }^{\star}$ Goethe University Frankfurt, goldmann@jur.uni-frankfurt.de; Max Planck Institute for Comparative Public Law and International Law, goldmann@mpil.de. Thanks to Pawel Filipek for crucial information on the Polish situation.

${ }^{1}$ BVerfG, Nov. 6, 2019, docket number 1 BvR 16/13 - Right to be forgotten I; BVerfG, Nov. 6, 2019, docket number 1 BvR 276/17 - Right to be forgotten II.

${ }^{2}$ E.g. Thomas Kleinlein, Neue starke Stimme in der europäischen Grundrechts-Polyphonie, VERFBLOG, Dec. 1, 2019, https://doi.org/10.17176/20191201-180539-0; Matej Avbelj, The Federal Constitutional Court Rules for a Bright Future of Constitutional Pluralism, in this issue.

${ }^{3}$ E.g. Dana Burchardt, Backlash against the Court of Justice of the EU? The Recent Jurisprudence of the German Constitutional Court on EU Fundamental Rights as a Standard of Review, in this issue.
}

(C) The Author(s) 2020. Published by Cambridge University Press on behalf of the German Law Journal. This is an Open Access article, distributed under the terms of the Creative Commons Attribution-NonCommercial-ShareAlike licence (http://creativecommons.org/ licenses/by-nc-sa/4.0/), which permits non-commercial re-use, distribution, and reproduction in any medium, provided the same Creative Commons licence is included and the original work is properly cited. The written permission of Cambridge University Press must be obtained for commercial re-use. 
progressive reading of the EU Charter of Fundamental Rights (the Charter). Opinions mainly diverge on whether Karlsruhe's latest move is to be qualified as potentially constructive or obstructive to the amicability of the courts' relationship and ultimately also for legal certainty. ${ }^{4}$

In this note, I would like to shed light on a substantially different aspect of the decision that may put the predominant focus of commentators on judicial dialogue somewhat in perspective. While there is no point in denying the significance of the Right to be forgotten for the state of judicial dialogue in Europe (B.), restricting the scope of analysis to the narrow context of judicial dialogue misses the wider context of the rise of authoritarian constitutionalism in many of the (present and former) Member States. ${ }^{5}$ Not only the concern some of the members of the First Senate have shown for the ongoing assault on the judiciary in Poland suggests such a reading, but also the judgment itself. As a matter of fact, the decisions on the Right to be forgotten effectively eliminate the imagined normative hierarchy that underpinned the BVerfG's stance towards European law ever since Solange I and Maastricht. ${ }^{6}$ After the Right to be forgotten, the BVerfG's long-standing default assumption underpinning these cases that the fundamental rights protections granted by the Basic Law are superior to those of the Union legal order no longer holds. Instead, the BVerfG vindicates the CJEU as a preceptor of fundamental rights vis-à-vis domestic courts, presumably in recognition of its crucial role in defending Europe against authoritarian constitutionalism. This hierarchical reshuffling makes it a lot less plausible, though not theoretically impossible, to invoke constitutional identity against measures of the Union that allegedly violate domestic fundamental rights. It might even open the gates for a "Reverse Solange", for measuring domestic law by the standards enshrined in Article 2 TEU (C.). The BVerfG may therefore no longer serve as a reference point for authoritarian constitutionalists justifying non-compliance with EU law by reference to their domestic constitutional identity. Hence, as the darkness deepens over democracy in Europe, with the Right to be forgotten, BVerfG joins forces with the CJEU in resisting it (D.).

\section{B. The Narrow Context: Catching up on Data Protection}

There is little doubt about the plausibility of reading the Right to be forgotten decisions as opening a new chapter in judicial dialogue. In fact, the subject matter of the cases at issue, data protection, may even give rise to a more antagonistic reading of these two decisions. Seen through that lens, one might argue that the BVerfG attempts to regain lost territory in a field for whose creation it was instrumental several decades ago. In fact, Germany used to be a thought leader in data protection. In 1970, the State of Hesse adopted the first data protection act in the world, soon to be followed by other states and by the federal government. In 1983, the BVerfG greatly boosted the quality of data protection in its census judgment (Volkszählung). ${ }^{7}$

Before rendering the Right to be forgotten, however, the refusal of the BVerfG to review domestic decisions applying fully harmonized Union law caused a decline in its significance in the field of data protection and ushered in the rise of the CJEU as the principal defender of privacy rights in Europe and perhaps worldwide. ${ }^{8}$ The cases decided by the CJEU over the last couple of years only constitute the tip of the iceberg. They still mostly concern the now-defunct, much more limited

\footnotetext{
${ }^{4}$ On the latter: Karsten Schneider, The Constitutional Status of Karlsruhe's Novel "Jurisdiction" in EU Fundamental Rights Matters: Self-inflicted Institutional Vulnerabilities, in this issue.

${ }^{5}$ I define "authoritarian constitutionalism" as a description of constitutional practice in weak democracies where the constitution, instead of limiting governmental powers, is used to entrench the ruling circle's power and ideology. See Roberto Niembro Ortega, Conceptualizing Authoritarian Constitutionalism, 49 Verfassung UND RECHT IN ÜBERSEE / LAw ANd Politics In Africa, Asia ANd Latin America 339, 341 (2016). Attributing to authoritarian constitutions mainly a signaling function: Mark Tushnet, Authoritarian Constitutionalism, 100 CoRNELL L.R. 391, 422 (2015).

${ }^{6}$ BVerfG, Oct. 12, 1993, docket number 2 BvR 2134/92, 2 BvR 2159/92 - Maastricht, 89 BVERFGE 155.

${ }^{7}$ See, e.g., BVerfG, Dec. 15, 1983, docket number 1 BvR 209, 269, 362, 420, 440, 484/83 - Volkszählung, 65 BVERFGE 1.

${ }^{8}$ Christopher Docksey \& Hielke Hijmans, The Court of Justice as a Key Player in Privacy and Data Protection, 5 EUROPEAN Data Protection Law Review 300 (2019).
} 
Data Protection Directive, ${ }^{9}$ while the full effects of the General Data Protection Regulation $(\mathrm{GDPR})^{10}$ on the judicial dialogue among Europe's most eminent courts remain to be seen for the better part.

In addition, even where the law was not fully harmonized and the BVerfG retained some of its powers of review, the BVerfG did not always emerge as the spearhead of legal innovation regarding new technologies, while the CJEU hardly wasted an opportunity. The BVerfG had fueled high expectations by recognizing a fundamental right to the confidentiality and integrity of information systems in 2008 in response to online searches by law enforcement authorities. ${ }^{11}$ However, it failed to deliver only two years later in the dispute concerning the Data Retention Directive, in which the CJEU embarrassed the BVerfG and other equally cautious, eminent courts in the Member States by quashing the directive. ${ }^{12}$ Formally, the CJEU and domestic courts looked into slightly different matters in their decisions, the former into the compatibility of the Data Retention Directive with the primary law, the latter into domestic implementing legislation. Substantively, however, the two issues could hardly be separated from one another, as the proportionality of indiscriminate data retention depends on many factors regulated partly by European law, partly by domestic law. Instead of looking at data retention holistically, the BVerfG, like many of its peers in other member states, ${ }^{13}$ confined itself to fiddling with the implementing legislation, trimming somewhat the potential use to be made of the retained data, and refused to refer the case to the CJEU. ${ }^{14}$ The CJEU's judgment, by contrast, displayed the proverbial big picture, questioning the well-worn anti-terrorism rhetoric supporting the directive and refusing to let the ends justify the means. ${ }^{15}$ One might draw from this the conclusion that restricting one's focus as narrowly as the BVerfG can significantly reduce the quality of fundamental rights protection. Cumulative effects caused by the interplay of European and domestic law get out of sight if the European part of the legal situation is eclipsed to avoid a referral in accordance with Article 267 TFEU.

In a later round, the BVerfG tried to restore its erstwhile leadership position in data protection. In reaction to the CJEU's extensive reading of the Charter's scope of application to cases only indirectly affected by secondary law in Akerberg Fransson, ${ }^{16}$ the BVerfG formulated a twofold response in its Antiterrorism Database decision: ${ }^{17}$ First, it kept the CJEU out of the case by holding it to be an acte clair the EU Data Protection Directive did not apply; ${ }^{18}$ second, it restricted access by police authorities to the database of terror suspects at issue and ordered special protection for persons indirectly affected. One could read the judgment in the sense that only the former allowed the latter, i.e. that only rigorous exclusion of the CJEU allowed the BVerfG, given its limited scope of review of acts implementing EU law, to assess the matter holistically and engage in a differentiated, contextualizing proportionality analysis. Its further success in reprimanding intrusions into privacy, therefore, seemed to stand on shaky grounds as it would not always be able to frame a dispute as falling outside the possible scope of EU law.

\footnotetext{
${ }^{9}$ Directive 95/46/EC of the European Parliament and of the Council of 24 October 1995 on the protection of individuals with regard to the processing of personal data and on the free movement of such data, 1995 O.J. (L 281 ) 31.

${ }^{10}$ Regulation (EU) 2016/679 of the European Parliament and of the Council of 27 April 2016 on the protection of natural persons with regard to the processing of personal data and on the free movement of such data, and repealing Directive 95/46/ EC (General Data Protection Regulation), 2016 O.J. (L 119) 1.

${ }^{11}$ BVerfG, Feb. 27, 2008, docket number1 BvR 370/07, 120 BVERFGE 274

${ }^{12}$ CJEU, Case C-293/12 and 594/12, Digital Rights Ireland, Apr. 8, 2014, ECLI:EU:C:2014:238.

${ }^{13}$ Overview in Ludovica Benedizione \& Eleonora Paris, Preliminary Reference and Dialogue Between Courts as Tools for Reflection on the EU System of Multilevel Protection of Rights: The Case of the Data Retention Directive, 16 GER. L.J. 1727, 1734 (2019).

${ }^{14}$ BVerfG, Mar. 2, 2010, docket number 1 BvR 256/08, 125 BVERFGE 260, 308, para. 185.

${ }^{15}$ CJEU, Case C-293/12 and 594/12, Digital Rights Ireland, Apr. 8, 2014, ECLI:EU:C:2014:238, paras. 56-64.

${ }^{16}$ CJEU, Case C-617/10, Åkerberg Fransson, ECLI:EU:C:2013:105.

${ }^{17}$ BVerfG, 24 Apr. 24, 2013, docket number 1 BvR 1215/07, 133 BVERFGE 277, para. 91 (making it explicit that the judgment is a reaction to Akerberg Fransson.)

${ }^{18} I d$., at para. 90.
} 
While the scope of application of EU law has allowed the BVerfG to further develop its progressive line concerning data privacy intrusions by the state or to regulate online hate speech, ${ }^{19}$ the BVerfG lost its leadership role to the CJEU in setting up rules for the market for private data, an issue falling under the Data Protection Directive. ${ }^{20}$ Thus, it was for the CJEU to invent the right to be forgotten in Google Spain ${ }^{21}$ and to uphold European data protection standards against Facebook in Schrems. ${ }^{22}$ It also falls upon the CJEU to carve out the international reach of EU data privacy rules. ${ }^{23}$

These dynamics between the two courts matter a lot, economically, politically, and symbolically. The commodification of data seems to be not only a key aspect of capitalism in the 21st century, for which (private) data is the new capita seeking legal protection. ${ }^{24}$ What is more, privately collected data may be acceded by governments where the data is stored or the company seated control. It increases their level of control over people as strategic and operative collaboration between economic actors and government intensifies. ${ }^{25}$

With the entry into force of the GDPR, it became too late for the BVerfG to change the situation. The CJEU will become the court of reference for setting the rules of the information society. ${ }^{26}$ This restricts the possibility of the BVerfG to pronounce itself on more than marginal aspects of the rules relating to horizontal data protection and increases the risk that its assessments will lack a holistic perspective due to the attempt to skirt questions of EU law. From this perspective, the Right to be forgotten appears as a necessary step to regain relevance for this matter ${ }^{27}$ and contribute to EU law by, e.g., developing doctrines relating to the horizontal application of fundamental rights. ${ }^{28}$

Moreover, one could read the many questions left open by the judgment ${ }^{29}$ as a continuation of the familiar logic of "mutually assured discretion". It was precisely by keeping the applicable standards and reciprocal "red lines" uncertain that judicial dialogue has stabilized the relationships between the CJEU and courts in the Member States. As long as there is a desire to avoid open clashes, indeterminate standards instill a modicum of self-discipline in each participant in the judicial dialogue. ${ }^{30}$ Under these conditions, courts can never be sure if the step they are pondering to take would be one step too far and lead to non-compliance or generally undermine its position. Is the First Senate thus following in the footsteps of the Second Senate, whose intransigence in respect of the CJEU left its marks in the Economic and Monetary Union, reaching another peak

\footnotetext{
${ }^{19}$ See, e.g., BVerfG, Aug. 27, 2019, docket number 1 BvR 811/17.

${ }^{20}$ Indra Spiecker genannt Döhmann, A New Framework for Information Markets: Google Spain, C.M.L.REV. 1033 (2015).

${ }^{21}$ CJEU, Case C-131/12, Google Spain v APED, ECLI:EU:C:2014:317.

${ }^{22} \mathrm{CJEU}$, Case C-362/14, Schrems, ECLI:EU:C:2015:650.

${ }^{23}$ Federico Fabbrini \& Edoardo Celeste, The Right to Be Forgotten in the Digital Age: The Challenges of Data Protection beyond Borders, in this issue. In transatlantic comparative perspective: David Cole \& Federico Fabbrini, Bridging the Transatlantic Divide? The United States, the European Union, and the Protection of Privacy Across Borders, 14 INT'L J. CONST. L. 220 (2016).

${ }^{24}$ On genealogies of coding capital, see Katharina Pistor, The Code of Capital: How the Law Creates WeAlth AND Inequality (2019). On private data as the new capital, see Shoshana Zuboff, The Age of Surveillance Capitalism: The Fight for a Human Future at the New Frontier of Power (2019).

${ }^{25}$ Gyula Csurgai, The Increasing Importance of Geoeconomics in Power Rivalries in the Twenty-First Century, 23 Geopolitics 38 (2018).

${ }^{26}$ E.g. BVerwG, Sep. 11, 2019, BVerwG 6 C 15.18 (on embedded facebook "like" buttons on a fan page), reacting to CJEU, Case C-40/17, Fashion ID GmbH, ECLI:EU:C:2019:629.

${ }^{27}$ Kleinlein, supra note 2.

${ }^{28}$ BVerfG, Nov. 6, 2019, docket number 1 BvR 276/17 - Right to be forgotten II, para. 97.

${ }^{29}$ E.g. Karsten Schneider, The Constitutional Status of Karlsruhe's Novel "Jurisdiction" in EU Fundamental Rights Matters: Self-inflicted Institutional Vulnerabilities, in this issue.

${ }^{30}$ Ana Bobić, Constitutional Pluralism Is Not Dead: An Analysis of Interactions between Constitutional Courts of Member States and the European Court of Justice, 18 GER. L.J. 1395 (2017); Matthias Goldmann, Discretion, not rules: postunitary constitutional pluralism in the Economic and Monetary Union, in RESEARCH HANDBOoK ON LEGAL PluRALISM AND EU LAW 335 (Matej Avbelj \& Gareth Davis eds., 2018).
} 
in the recent Banking Union decision that confirmed once more the logic of mutually assured discretion? ${ }^{31}$ From this perspective, nothing much has changed at the level of judicial dialogue with the Right to be forgotten, except that the BVerfG has now lost its inhibitions to step on the stamping ground of the CJEU, dropping its erstwhile strategy of splendid legal isolation.

\section{The Wider Context: Wither the Authoritarian Threat}

As plausible as the aforementioned account may appear, it turns out to be inchoate if seen from a different angle. That angle is the current constitutional crisis in Europe, the wider context in which I believe the position of the BVerfG in the Right to be forgotten needs to be read.

Fast falls the eventide of the rule of law in some Member States. Liberal democracy and constitutionalism become symbols for a widespread sense of alienation in Central and Eastern Europe, in which the unfinished homework of the democratic transition some thirty years ago and popular disappointment about the social development since then culminates. ${ }^{32} \mathrm{~A}$ variety of nationalistic leaders travel on this wave to establish increasingly autocratic forms of government. ${ }^{33}$

International human rights courts have been among the first victims of this development, as they allow nationalists and other opponents of the rule of law to broaden their angle of attack by combining anti-liberal and anti-international resentments. The European Court of Human Rights occasional self-censorship and restraint reflects the chilling effect of such political pressure, amplified by domestic courts questioning its position as a supreme interpreter of the Convention. ${ }^{34}$ These forces rendered the Council of Europe too weak to resist Russia's outright contempt for the Court. ${ }^{35}$ The Inter-American Court of Human Rights has faced different, but partly related challenges. ${ }^{36}$ In some cases, the confrontational position of governments against the Court did indeed resonate with considerable parts of the public, whereas in other cases, authoritarian governments simply tried to rid themselves of a critical voice even against support for the Court in civil society. ${ }^{37}$

Perhaps more crucial from the perspective of the BVerfG might have been how the various backstops against European law carved out essentially by the Second Senate turned sour while spreading across the Union. The Czech Constitutional Court's claim that the CJEU had acted ultra vires in the Slovak Pensions case ${ }^{38}$ could still be read as collateral damage resulting from a dispute

\footnotetext{
${ }^{31}$ BVerfG, Jul. 30, 2019, docket number 2 BvR 1685/14, para. 194 et seq. (where the BVerfG re-reads the L-Bank decision of the General Court, Case T-122/15, ECLI:EU:T:2017:337, arguing that the view expressed by the General Court that the SSM Regulation gives the ECB exclusive supervisory powers, which it needs to delegate back to National Competent Authorities, would be ultra vires).

${ }^{32}$ Tomasz Tadeusz Koncewicz, The Capture of the Polish Constitutional Tribunal and Beyond: Of Institution(s), Fidelities and the Rule of Law in Flux, 43 Review of Central and EASt European Law 116 (2018); Bojan Bugaric, Populism, Liberal Democracy, and the Rule of Law in Central and Eastern Europe, 41 CommUNIST AND PosT-CommUNIST STUDIES 191, 198 (2008).

${ }^{33}$ Kim Lane Scheppele, The Opportunism of Populists and the Defense of Constitutional Liberalism, 20 GER. L.J. 314 (2019).

${ }^{34}$ Basak Cali, Coping with Crisis: Whither the Variable Geometry in the Jurisprudence of the European Court of Human Rights, 35 WIS. INT'L LJ (2017); to what extent this might result in, and be justified by, questions of constitutional identity is discussed in Principled Resistance to ECtHR Judgments-A New Paradigm? (Marten Breuer ed. 2019).

${ }^{35}$ Russia and the European Court of Human Rights: The Strasbourg Effect (Lauri Mälksoo \& Wolfgang Benedek eds. 2017); Silvia Steininger, Managing the Backlash? The PACE and the Question of Participation Rights for Russia, VERFBLOG, Oct. 9, 2018, https://doi.org/10.17176/20181012-131857-0.

${ }^{36}$ Arguing for a global tide against human rights courts sweeping over from Europe: Jorge Contesse, Resisting the InterAmerican Human Rights System, 44 Yale J. INT'L L. 179 (2019).

${ }^{37}$ For a differentiated account: Ximena Soley \& Silvia Steininger, Parting ways or lashing back? Withdrawals, backlash and the Inter-American Court of Human Rights, 14 InTERnational JOURnal of LAW In CONTEXT 237 (2018).

${ }^{38}$ Czech Constitutional Court, Jan 31, 2012, docket number Pl. ÚS 5/12 - Slovak Pensions. The case follows up on CJEU, Case C-399/09, Landtóva, ECLI:EU:C:2011:415.
} 
among Czech courts. ${ }^{39}$ The Ajos judgment by the Danish Supreme Court raised different chords. ${ }^{40}$ Formally addressing the impact of the prohibition of age discrimination under Union law on Danish rules excluding severance payments for employees nearing retirement age, the case invited searches for more sinister motives. Accordingly, the Supreme Court may have used a wave of antiEuropean and anti-immigration sentiment to stand its ground against the CJEU. ${ }^{41}$ But it was for the "orbanized" Hungarian Constitutional Court ${ }^{42}$ to pervert the idea of constitutional identity as a safeguard against egregious human rights abuses by invoking the human rights of refugees to reject the Council's plans for a more equitable burden-sharing in refugee allocation. ${ }^{43}$

The development recently reached a climax with the recent assault of the judiciary in Poland. The ruling PiS party took aim at the judiciary early on, implementing a fast-paced sequence of measures including court-packing and other "reforms". The Commission sued Poland for violating the rule of law by lowering the retirement age for Polish Supreme Court judges ${ }^{44}$ and ordinary judges, ${ }^{45}$ succeeding eventually in both cases. However, the Polish ruling party had already launched new attacks in the form of two reforms relating to the disciplinary regime for judges adopted in 2019. They expose Polish judges to disciplinary measures if they "wrongly" apply EU law or make preliminary references to the CJEU. Although the Commission had meanwhile lodged another case against Poland before the CJEU against the new disciplinary chamber for the judiciary, ${ }^{46}$ the Polish government remained demonstratively unimpressed by adopting a disciplinary act in December 2019, which effectively challenges the primacy of EU law in these matters by exposing the judiciary to disciplinary sanctions for implementing EU law or making preliminary references. ${ }^{47}$ Despite wide-ranging international protests, the Polish government promptly enforced the new rules against a judge seeking to implement the judgment of the CJEU on judicial retirements. $^{48}$

The primacy of EU law thus became a key bone of contention in the Union's struggle with authoritarian governments in the Member States. I believe that this context cannot be ignored when evaluating the Right to be forgotten. For one, the timing corroborates this view. The BVerfG decided the case on the day after the CJEU had decided that lowering the retirement age of ordinary judges violated Article 19 para. 1 TEU. ${ }^{49}$ An earlier case had already been decided and a third case was pending while the BVerfG brooded over its decision. ${ }^{50}$

For two, the current composition of the Court and the views expressed by some of its members suggest that the rule of law crisis in Europe may have played a role for the Right to be forgotten.

\footnotetext{
${ }^{39}$ Jan Komárek, Czech Constitutional Court Playing with Matches: The Czech Constitutional Court Declares a Judgment of the Court of Justice of the EU Ultra Vires; Judgment of 31 January 2012, Pl. US 5/12, Slovak Pensions XVII, 8 EUR. CONST. L.R. 323 (2012).

${ }^{40}$ Supreme Court of Denmark, Dec. 6, 2016, Case no. 15/2014 - Dansk Industri (DI) acting for Ajos A/S vs. The Estate left by A.

${ }^{41}$ Mikael Rask Madsen, et al., Competing Supremacies and Clashing Institutional Rationalities: the Danish Supreme Court's Decision in the Ajos Case and the National Limits of Judicial Cooperation, 23 EuR. L.J. 140, 148 (2017).

${ }^{42}$ Cf. Gábor Halmai, Populism, Authoritarianism and Constitutionalism, 20 GER. L.J. 296, 302 et seq. (2019).

${ }^{43}$ Ágoston Mohay \& Norbert Tóth, Decision 22/2016. (XII. 5.) AB on the Interpretation of Article E)(2) of the Fundamental Law, 111 AMERICAN JOURNAL OF INTERNATIONAL LAW 468 (2017).

${ }^{44}$ CJEU, Case C-619/18, Commission v Poland, ECLI:EU:C:2019:531.

${ }^{45}$ CJEU, Case C-192/18, Commission v Poland, ECLI:EU:C:2019:924.

${ }^{46}$ CJEU, Case C-791/19, filed on Oct. 25, 2019.

${ }^{47}$ For a full account of the alarming measures taken by the Polish government, see Council of Europe, Poland - Joint Urgent Opinion of the Venice Commission and the Directorate General of Human Rights and Rule of Law (DGI) of the Council of Europe on Amendments to the Law on the Common Courts, the Law on the Supreme Court, and Some Other Laws, Jan. 16, 2020, CDL-PI(2020)002.

${ }^{48}$ The Disciplinary Chamber suspends Justice Pawel Juszczyszyn from his post and reduces his renumeration, IUSTITIA, Feb. 6 , 2020, https://www.iustitia.pl/en/disciplinary-proceedings/3680-the-disciplinary-chamber-suspends-justice-pawel-juszczyszynfrom-his-post-and-reduces-his-renumeration.

${ }^{49} \mathrm{CJEU}$, Case C-192/18, Commission v Poland, ECLI:EU:C:2019:924.

${ }^{50}$ Supra, notes 44 and 46.
} 
Since the First Senate's last "show of force" in the judicial dialogue saga in the Antiterrorism Database case, ${ }^{51}$ the composition of the First Senate has changed considerably. The presiding judge, former Vice President Ferdinand Kirchhof, retired. He is a brother of Paul Kirchhof, himself a former member of the Second Senate and the intellectual father of the Maastricht judgment. While it would be grossly misleading to classify the two brothers as Eurosceptics, they have been adamant in demanding a strict separation of competences between national courts and the CJEU, which is for them an essential precondition for preserving national (constitutional) identity. ${ }^{52}$ Ferdinand Kirchhof was replaced by the new vice president Stephan Harbarth, a former member of Bundestag. An advocate of pragmatic, yet economically and socially conservative positions in the Bundestag, he ended his parliamentary mandate right before joining the Court with a passionate speech in defense of the UN Global Compact for Migration, pleading for an integrative approach to domestic and supranational politics. ${ }^{53}$ It, therefore, seems plausible that the departure of Vice President Kirchhof opened a window of opportunity for rebalancing the First Senate's relationship with the CJEU, as described above. ${ }^{54}$ What is more, however, is that Harbarth has been exceptionally vocal for someone in his position in criticizing the demolition of the rule of law in Poland. ${ }^{5}$ Moreover, Johannes Masing, the most senior of the First Senate's Associate Justices and the court's reporter in the Right to be forgotten, is not only one of the few high-ranking German judges with a command of Polish, but also very well-connected with the Polish judiciary, especially with the embattled President of the Supreme Court, Małgorzata Gersdorf. ${ }^{56}$ Justice Susanne Baer has equally expressed her support for Polish colleagues on various occasions. ${ }^{57}$ It therefore seems that there is a critical mass of judges in the First Senate who are on the record for their deep concern about the situation of their Polish colleagues - a crisis whose legal gestalt revolves around the primacy of EU law.

For three, explaining judgments through the personal views of the judges is of course always to a certain extent speculative, not least because a bundle of motives and persons contributes to a single decision, among which the need to meet the public's expectations towards courts and legal rationality might not be the least important one. ${ }^{58}$ Also, the BVerfG has been remarkably consistent in its jurisprudence over time despite frequent changes in its composition. ${ }^{59}$ It would be an intellectual sin to turn a blind eye on such complexity. However, the content of the judgment confirms the impression that it has also to be read as a reaction to rampant authoritarianism in various Member States.

A first sign pointing in this direction is that the Right to be forgotten, like other decisions from recent years, cites other European courts extensively, which underlines the contextual sensitivity

\footnotetext{
${ }^{51}$ BVerfG, 24 Apr. 24, 2013, docket number 1 BvR 1215/07, 133 BVerfGE 277.

${ }^{52}$ Ferdinand Kirchhof, Kooperation zwischen nationalen und europäischen Gerichten, 49 EUR EUROPARECHT 267 (2014); Paul Kirchhof, Der deutsche Staat im Prozeß der europäischen Integration, in 7 HANDBUCH DES STAATSRECHTS DER BundesRepublik Deutschland $\$ 214$ no. 182 et seq. (Josef Isensee \& Paul Kirchhof eds., 1992).

${ }^{53}$ Deutscher Bundestag, Nov. 30, 2018, Plenary Protocol, 19th Bundestag, 69th Session, 8035-6.

${ }^{54}$ Part B.

55 "Die EU ist gefordert, Druck auf Polen zu entfalten", Interview, DeUTSCHLAndFunK, Jan. 12, 2020, https://www. deutschlandfunk.de/bverfg-vizepraesident-harbarth-die-eu-ist-gefordert-druck.868.de.html?dram:article_id=467427.

${ }^{56}$ Wolfgang Janisch, "Ich werde die erste Präsidentin im Exil sein", SüdDeUtsche ZeITUNG, Jul. 21, 2018, https://www. sueddeutsche.de/politik/praesidentin-des-obersten-gerichts-in-polen-ich-werde-die-erste-praesidentin-im-exil-sein-1.4064388.

${ }^{57}$ E.g. Dietrich Schröder, Wenn der Rechtsstaat ausgehöhlt wird, MOZ.DE, Dec. 13, 2018, https://www.moz.de/nachrichten/ brandenburg/artikel-ansicht/dg/0/1/1697643/.

${ }^{58}$ Andreas Grimmel, Judicial Interpretation or Judicial Activism? The Legacy of Rationalism in the Studies of the European Court of Justice, 18 EUR. L.J. 518, 525 et seq. (2012).

${ }^{59}$ See Oliver Lepsius, Die maßstabsetzende Gewalt, in DAs ENTGRENZTE GERICHT. EINE KRITISCHE BILANZ NACH SECHZIG JAHREN BundeSVERFASSUNGSGERICHT 159, 214 et seq. (Matthias Jestaedt, et al. eds., 2011) (tracing back this consistency to the BVerfG's idiosyncratic tradition of abstract reasoning, which makes distinguishing difficult without running into contradictions).
} 
of the BVerfG. ${ }^{60}$ This mindset is light-years ahead of the benign neglect shown in the 2004 Görgülü judgment for the transnational repercussions of BVerfG decisions. ${ }^{61}$ Understanding the situation of other European courts and challenges requires, first of all, following the developments there.

Second, of crucial importance for the argument advanced here is the confirmation of the primacy of the Charter in Right to be forgotten II. Remember, the impact of authoritarian constitutionalism on EU law consists mainly of challenging the primacy of EU law. It is exactly for the primacy of European law, more specifically, for the primacy of the rule of law principle guaranteed by Article 19 para. 1 TEU that the Polish judge was suspended. Against this background, it is of high symbolic significance that the BVerfG reasserts the primacy of EU law in fully harmonized situations. The court charged with protecting Germany's constitutional identity underlines that respect for the primacy of EU law, particularly for the Charter, is now part of a European court's decisionmaking routine. Moreover, preliminary references to the CJEU concerning the interpretation of the Charter will have to be made on the basis of Article 267 TFEU, instead of German constitutional law as in case of ultra vires control. ${ }^{62}$ This shift provides important argumentative support for courts willing to quash domestic acts because they violate fundamental principles of EU law, wherever the Charter applies. In this sense, it follows the CJEU's reasoning in LM (Celmer), where it charged domestic courts with defending the values enshrined in Article 2 TEU. ${ }^{63}$

Third, the way how the judgment defines the relationship between fundamental rights protection at the European and domestic levels is extremely instructive for the wider context of authoritarian constitutionalism. The entire Solange jurisprudence, including the stance taken in Banana Market Order, rested on an implicit hierarchy, i.e. on the assumption that European fundamental rights protection was still under probation, carefully watched by the Karlsruhe headmen and women. The Right to be forgotten I puts this assumption on its head simply by adding to that the rebuttable presumption that German fundamental rights protection in not fully harmonized fields would normally meet the standard of fundamental rights protection required by European law. ${ }^{64}$ Of course, the First Senate hastens to assure that the powers of review of the BVerfG as defined by the Banana Market Order, Lisbon, Honeywell, etc., would remain intact. ${ }^{65}$ But the mere act of adding to an existing presumption a second, diametrically opposed presumption changes the former presumption. Normativity is relative, and if one combines the two presumptions, one can no longer uphold the implicit view pervading the entire BVerfG jurisprudence until now that fundamental rights protection in Europe is ultimately less trustworthy and less genuine than the protection guaranteed by the BVerfG, wherefore the former requires the backup support of the latter. In other words, the Right to be forgotten shifts the relationship between German and European fundamental rights protection from hierarchy to heterarchy. ${ }^{6}$ Under this new situation, even if the BVerfG reactivates its fundamental rights review, as it did in the 2015 case on the European Arrest Warrant, ${ }^{67}$ it does no longer imply that European fundamental rights protection is deficient; it is merely different. ${ }^{68}$

\footnotetext{
${ }^{60}$ BVerfG, Nov. 6, 2019, docket number 1 BvR 276/17 - Right to be forgotten II, para. 50, 110.

${ }^{61}$ BVerfG, Oct. 14, 2004, docket number 2 BvR 1481/04, 111 BVERFGE 307.

${ }^{62}$ See Karsten Schneider, Der Ultra-vires-Maßstab im Außenverfassungsrecht Skizze sicherer Vollzugszeitumgebungen für zwischenstaatliche und supranationale Integrationsprozesse, 139 ARCHIV DES ÖFFENTLICHEN RECHTS 196, 248 (2014).

${ }^{63}$ CJEU, C-216/18 PPU, LM, ECLI:EU:C:2018:586, para. 69 et seq.

${ }^{64}$ BVerfG, Nov. 6, 2019, docket number 1 BvR 16/13 - Right to be forgotten I, para. 49.

${ }^{65}$ BVerfG, Nov. 6, 2019, docket number 1 BvR 276/17 - Right to be forgotten II, para. 47-49.

${ }^{66}$ See also Matej Avbelj, The Federal Constitutional Court Rules for a Bright Future of Constitutional Pluralism, in this issue.

${ }^{67}$ BVerfG, Dec. 15, 2015, docket number 2 BvR 2735/14, 140 BVERFGE 317 - European Arrest Warrant.

${ }^{68}$ Cf. BVerfG, Nov. 6, 2019, docket number 1 BvR 16/13 - Right to be forgotten I, para. 67. In this respect, the Right to be forgotten differs from the Austrian Constitutional Court, Mar. 14, 2012, docket number U 466/11-18, U 1836/11-13, whose elevation of the Charter to a standard of review was premised on the similarity of Charter guarantees and the fundamental rights enshrined in the Austrian constitution. See Andreas Orator, The Decision of the Austrian Verfassungsgerichtshof on the EU Charter of Fundamental Rights: An Instrument of Leverage or Rearguard Action?, 16 GER. L.J. 1429, 1434-5 (2015). On
} 
The hierarchical upgrade of European fundamental rights protection and European law thus deprives authoritarian constitutionalism of one of its strongest intellectual supporters. It might even open the theoretical possibility for a "Reverse Solange", i.e. for a situation where national law cannot be applied any longer irrespective of Art. 51 para. 1 of the Charter because it violates the constitutional identity of the EU, as defined by Article 2 TEU. ${ }^{69}$

\section{Conclusion: Abide with Each}

The Right to be forgotten is relevant on many levels. Taking them together, the double decision appears as an ingenious move. Not only points it to an escape route from the dead-end in judicial dialogue into which the Second Senate maneuvered itself with its ultra vires decisions. This line of decisions has been entrapped by the difficulty of disentangling deeply entangled competencies ${ }^{70}$ to the point where it overstepped its own competencies while hunting down transgressions of the EU's competencies. ${ }^{71}$ Similarly, one might wonder about the value of a decision which insists, contra the General Court, that the powers of national supervisory authorities within the Single Supervisory Mechanism are original and not derivative of the ECB - even though making this point had no impact on the repartition of supervisory powers beyond the symbolical. ${ }^{72}$

Moreover, the BVerfG strengthens the back of colleagues under threat from authoritarian constitutionalism. It narrows the scope for arguments building on constitutional identity to undermine obligations deriving from European law. In fact, the reliance on constitutional identity invented by the BVerfG has given rise to a peculiar split in the idea of law in the minds of authoritarian constitutionalists. For them, there exist two layers, the first one being the ever-expanding, formally legal but substantively doubtful European law, which contrasts with the romanticized idea of a primordial, supposedly static, and endangered national constitutional identity on the other. ${ }^{73}$ The latter has pre-positive roots, which serve as an argument to subordinate the former to it. Or, in the words of the former Senior Marshall of the Polish Sejm, "above the law, there is the well-being of the nation". ${ }^{44}$ This idea of pre-positive law is not only anti-European and anti-international. It resonates with an entire bunch of anti-modern and anti-pluralistic ideas prevalent in authoritarian constitutionalist circles. From this angle, the First Senate's introduction of a heterarchy between European and domestic constitutional law could hardly be underestimated. The simple recognition that the Charter may at times offer superior protection to the citizens than the one afforded by the domestic constitution makes the whole authoritarian constitutionalist edifice collapse. The fan club which the BVerfG enjoys in circles supportive

persisting differences between BVerfG and CJEU regarding proportionality control, see Klaus Ferdinand Gärditz, Grundrechts-Mobile statt starrer Kompetenzschichten: Die Beschlüsse des BVerfG in „Recht auf Vergessenwerden I \& II", VERFBLOG, Jan. 19, 2020, https://verfassungsblog.de/grundrechts-mobile-statt-starrer-kompetenzschichten/.

${ }^{69}$ See Armin von Bogdandy, et al., Reverse Solange-Protecting the Essence of Fundamental Rights against EU Member States, 49 Common Market L. ReV. 489 (2012). For a recent update reflecting the CJEU's reliance on Art. 2 TEU instead of union citizenship, see Armin von Bogdandy \& Luke Dimitrios Spieker, Countering the Judicial Silencing of Critics: Article 2 TEU Values, Reverse Solange, and the Responsibilities of National Judges, 15 EUR. CONST. L. Rev. 426 (2019).

${ }^{70}$ Jürgen Bast, Don't Act Beyond Your Powers: The Perils and Pitfalls of the German Constitutional Court's Ultra Vires Review, 15 GER. L.J. 167, 175 (2014).

${ }^{71}$ Franz C Mayer, Rebels Without a Cause? A Critical Analysis of the German Constitutional Court's OMT Reference, 15 GER. L.J. 111, 137 (2014).

${ }^{72}$ Supra note 31 .

${ }^{73}$ On the populist potential of constitutional identity, see Andrea Pin, The Transnational Drivers of Populist Backlash in Europe: The Role of Courts, 20 GER. L.J. 225, 233 (2019). On the static vs. dynamic character of constitutional identity, see Jürgen Bast \& Liav Orgad, Constitutional Identity in the Age of Global Migration, 18 GER. L.J. 1587, 1591 (2017); Christian Walter \& Markus Vordermayer, Verfassungsidentität als Instrument richterlicher Selbstbeschränkung in transnationalen Integrationsprozessen, 63 JAHRBUCH DES ÖFFENTLICHEN RECHTS 129 (2015).

${ }^{74}$ Speech by MP Kornel Morawiecki, Stenographic Report of the 2nd Session of the Sejm of the Republic of Poland, Nov 25, 2015, 78 (own translation). 
of the Alternative für Deutschland will probably reconsider its views after the Right to be forgotten, and one can only hope that the decision will have similar effects on like-minded groups in other Member States.

Lastly, the BVerfG recognizes with this decision that the CJEU is one of the last institutions standing and shining through the gloom of rising authoritarian constitutionalism. Crucial to its position is, and was, the primacy of European law. It empowers members of national judiciaries on shrinking islands of judicial independence to discard incompatible national law and to call upon the CJEU for support. In this given context, the BVerfG chooses to abide, not to fight. One might wonder whether it accidentally found the true meaning of constitutional identity.

Cite this article: Goldmann M (2020). As Darkness Deepens: The Right to be Forgotten in the Context of Authoritarian Constitutionalism. German Law Journal 21, 45-54. https://doi.org/10.1017/glj.2020.18 